\title{
DETERMINATION OF THE TEMPERATURE INFLUENCE ON THE CHANGE OF YOUNG'S MODULUS
}

\author{
Jiří SOBOTKA, Pavel SOLFRONK, David KOREČEK
}

TUL - Technical University of Liberec, Liberec, Czech Republic, EU, iiri.sobotka@tul.cz, pavel.solfronk@tul.cz, david.korecek@tul.cz

https://doi.org/10.37904/metal.2019.822

\begin{abstract}
Materials commonly used in various branches of the engineering industries are very often tested under basic conditions. This is due not only to the frequent effort to determine e.g. mechanical properties of the tested material just under reference conditions but also to the assumption that some material characteristics remain constant over the entire range of material loading conditions. In this paper, the change of Young's modulus in dependence on temperature is studied. Stainless steel was selected as the test material. To determine the required Young's modulus of elasticity, a static tensile test was performed on a testing machine equipped with a split tube furnace which allowed the desired loading temperature to be adjusted (generally from RT to about $1,400{ }^{\circ} \mathrm{C}$ ). The force channel was thus detected by means of a load cell (using bridge strain-gauge circuit) clamped in a testing machine. Specimen extension was simultaneously monitored using the external Mercury contact-less optical system, where the actual distance between two monitored points was measured. The entire system thus functioned as a "virtual" strain-gauge delivering the necessary specimen extension channel. From these measured characteristics, the corresponding Young's modulus of elasticity was finally calculated as a function of temperature. The resulting temperature influence on the values of Young's modulus change not only gives a better insight into the deformation behaviour of the tested material in the elastic deformation area, but can be also used in the numerical simulations of deformation processes.
\end{abstract}

Keywords: Young's modulus, temperature, static tensile test, optical system, stainless steel

\section{INTRODUCTION}

Young's modulus (or elastic modulus) represents, together with e.g. Poisson's ration, one of the most important deformation material characteristics in the elastic region - thus in the elastic deformation. Its value can be graphically explained with the help of linear extrapolation of true stress $\sigma$ from the elastic region up to true strain $\varepsilon=1.0$. Young's modulus is especially important when it comes to stiffness properties [1]. In light of atomic scale, its magnitude is primarily given by the interatomic bonds within the relevant crystal lattice. However, these are greatly influenced at the elevated temperatures and such change of properties is really necessary to take into account in situations of fire exposure. That's why in this paper was investigated change of Young's modulus upon temperature for stainless steel DIN 1.4301 (X5CrNi18-10).

The temperature effect on the mechanical response of engineering materials is (in light of temperature stressstrain rate relation) quite extensively described e.g. in work of Hertzberg [2]. In their works Ashby and coworkers used so-called deformation-mechanism maps to reveal stress-temperature dependences for different material groups. Moreover, Ashby used material property charts to show a lot of material properties in dependence on each other or different environment conditions - including temperature [3]. These charts can be very useful especially during the material selection. Own determination of the material mechanical properties (generally formability testing - in this case Young's modulus) is described in e.g. [4,5].

There have already been done a lot of different researches about influence of elevated temperatures on the mechanical properties of different types of stainless steels - e.g. [6]. Major differences can be found in the chosen methodologies and thus accuracy of these measurements. 


\section{METHODOLOGICAL BASES - TESTING MATERIAL AND PREPARATION OF SPECIMENS}

As a testing material there was used stainless steel DIN 1.4301 (AISI 304). It is austenitic stainless steel with EN symbol (short) as X5CrNi18-10. Its basic mechanical properties (under the room temperature - RT) are summarized in Table 1. Nevertheless, the major focus of this paper was concerned about determination dependence of the Young's modulus on temperature and these properties were not further monitored here.

Table 1 Basic mechanical properties of tested stainless steel DIN 1.4301

\begin{tabular}{|c|c|c|c|c|c|}
\hline \multicolumn{2}{|c|}{$\begin{array}{l}\text { Basic mechanical } \\
\text { properties }\end{array}$} & $\begin{array}{l}\text { Proof yield } \\
\text { strength } \\
\mathrm{R}_{\mathrm{p} 02}(\mathrm{MPa}) \\
\end{array}$ & $\begin{array}{c}\text { Ultimate tensile } \\
\text { strength } \\
\mathbf{R}_{\mathrm{m}}(\mathrm{MPa}) \\
\end{array}$ & $\begin{array}{l}\text { Uniform ductility } \\
\qquad \mathbf{A}_{\mathrm{g}}(\%)\end{array}$ & $\begin{array}{l}\text { Total ductility } \\
\text { A } 50 \mathrm{~mm}(\%)\end{array}$ \\
\hline $\begin{array}{c}\text { Stainless } \\
\text { steel }\end{array}$ & $\begin{array}{c}\text { arithmetic } \\
\text { mean } \mathbf{x}\end{array}$ & 331.2 & 654.3 & 45.22 & 50.62 \\
\hline DIN 1.4301 & $\begin{array}{c}\text { standard } \\
\text { deviation s }\end{array}$ & 5.2 & 6.1 & 0.23 & 0.37 \\
\hline
\end{tabular}

Influence of elevated temperatures (from $100^{\circ} \mathrm{C}$ up to $600^{\circ} \mathrm{C}$ ) was measured in the split tube furnace and by the contact-less optical system. But precise magnitude of Young's modulus under the RT was determined by the universal tensile testing machine TIRAtest 2300 and high accuracy axial extensometer Epsilon model 3542 that is shown in Figure 1a. Subsequent data processing was performed in the same way for all used temperatures and is in detail described in chapter 3. Due to the application of non-contact extensometer (via a mono-camera), there was firstly needed to prepared the own testing specimens - see Figure $1 \mathbf{b}$. Specimens of diameter $6 \mathrm{~mm}$ were machined and provided with threads. After their degreasing, there was applied stochastic (random) pattern that is scanned by the camera and where can be subsequently computed e.g. true strain distribution or just distance point-point, which was used in this case. So specimens were firstly sprayed by the ceramic black colour and then white spray was used to create small white dots on black background. Optical system requires such pattern, because it allocates the whole scanned surface onto facets in pixels and during measurement it just follows movement of these facets.

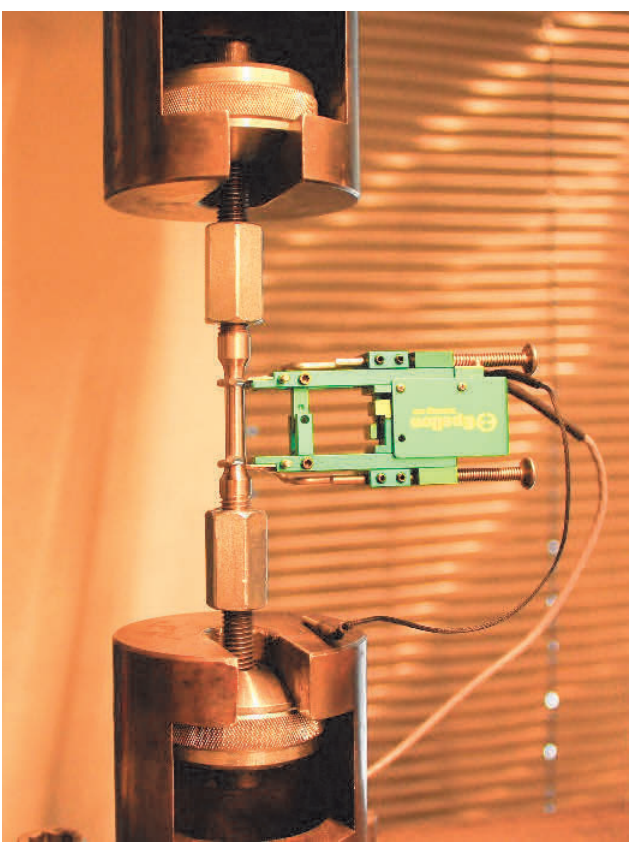

a) extensometer Epsilon model 3542

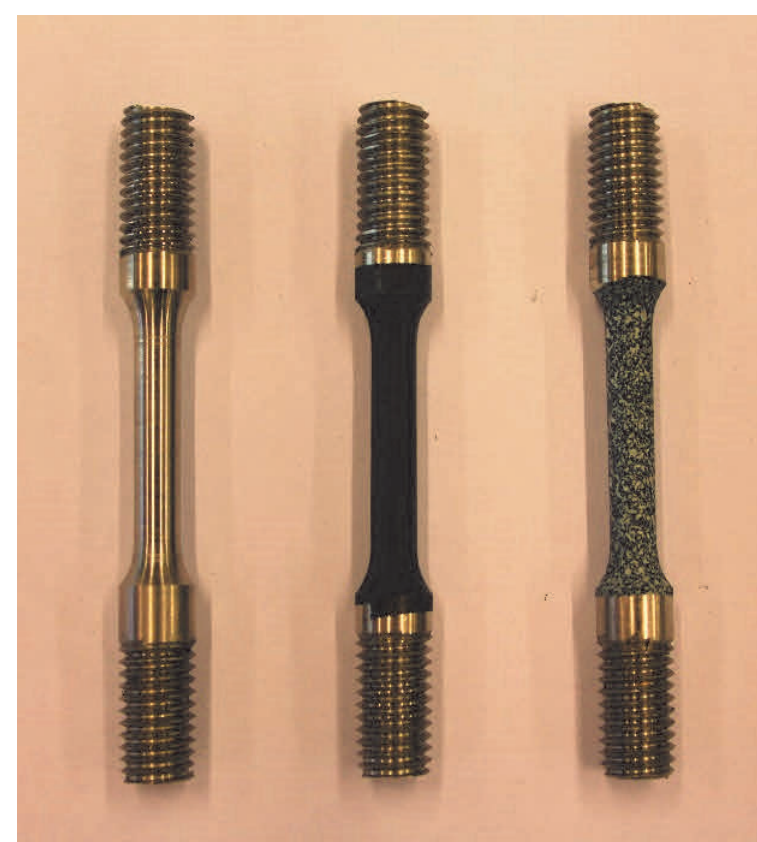

b) surface pattern on testing specimens

Figure 1 Axial extensometer Epsilon model 3542 and surface pattern on testing specimens 


\section{EXPERIMENTAL PART AND RESULTS}

Own testing of the temperature influence on the magnitude of Young's modulus was performed on the universal testing machine TESTOMETRIC FS100CT, which was equipped with the vertical high-temperature split tube furnace SOP 40x200/140 (see Figure 2). Thus force channel was measured by means of load cell in the testing machine. Extension of sample was simultaneously measured with the help of contact-less optical system Mercury RT v2.8 from Sobriety, Ltd. Regarding the utilization of cameras (just to measure distance between two points that serves as "virtual" extensometer), thus only one camera was used in this experiment. Specimens were prepared acc. to method that was described on the previous page and via threads were clamped in the centre of vertical split tube furnace.

Three was also important to adjust the contact-less optical system (here it consists just of mono-camera and lighting - see Figure 2) via its proper positioning (distance from the sample was $40 \mathrm{~cm}$ ) and calibration by calibration panel with the distance of $5 \mathrm{~mm}$. The blue lighting was used just because of high-temperature testing to avoid negative influence on camera from the thermal emissivity. Subsequently, the tube furnace was closed and before own heating of the sample, via the small "window" there was always performed the acquisition of image to check the position and scanned area. Finally, before the measurement of given stressstrain curves, the sample was heat up in the closed tube furnace on the relevant temperature.

There were used 7 testing temperatures - namely RT, $100^{\circ} \mathrm{C}, 200{ }^{\circ} \mathrm{C}, 300{ }^{\circ} \mathrm{C}, 400{ }^{\circ} \mathrm{C}, 500{ }^{\circ} \mathrm{C}$ and $600{ }^{\circ} \mathrm{C}$. As was already mentioned before, testing under RT was carried out with the high-accuracy axial extensometer (see Figure 1a). The other testing was performed with the help of tube furnace and camera. Due to the regulation of heating power, sometimes it was very time consuming testing (e.g. $3 \mathrm{hrs}$ to get on $600{ }^{\circ} \mathrm{C}$ ). After that, the experimental measurement of force $F$ and absolute extension $\Delta L$ was started simultaneously.

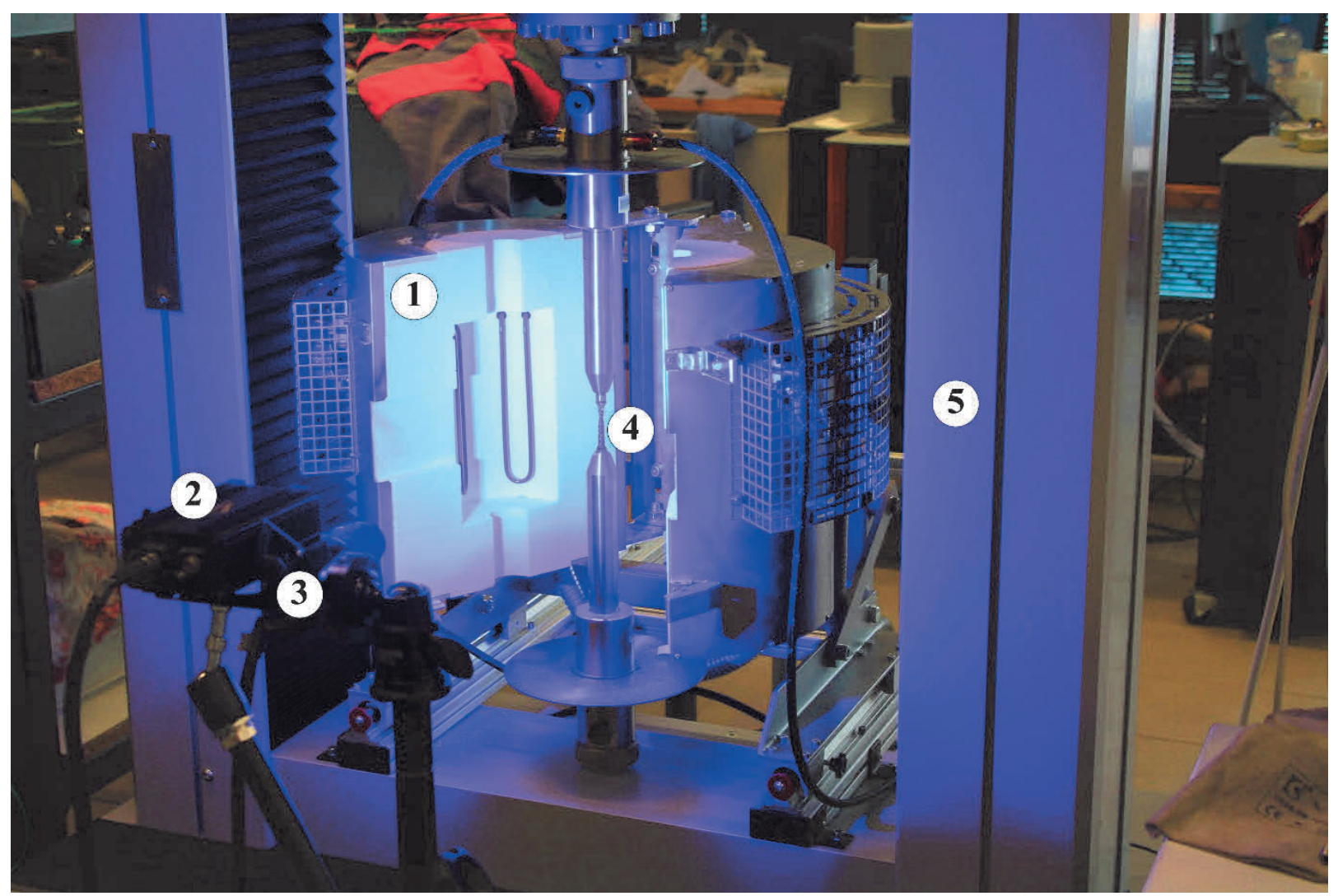

Figure 2 Workplace lay-out (1 - vertical split tube furnace SOP 40x200/140, 2 - lightning, 3 - camera, 4 - testing specimen, 5 - universal testing machine TESTOMETRIC FS100CT) 
From the measured force-elongation curves were in the software LabNET computed relevant engineering stress-strain curves and determined mechanical properties (not mentioned here). In Figure 3a is shown such measured engineering stress-strain curve for testing temperature $100{ }^{\circ} \mathrm{C}$. Subsequently, from the region of elastic deformation, there were within the interval from $30 \mathrm{MPa}$ up to $300 \mathrm{MPa}$ taken data to compute Young's modulus $E(\mathrm{MPa})$ by the least square method. Such procedure is shown in Figure 3b.

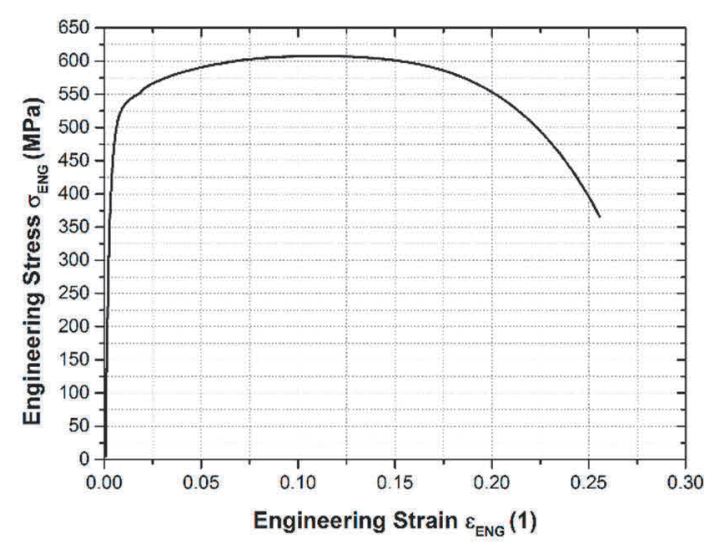

a) engineering stress-strain curve

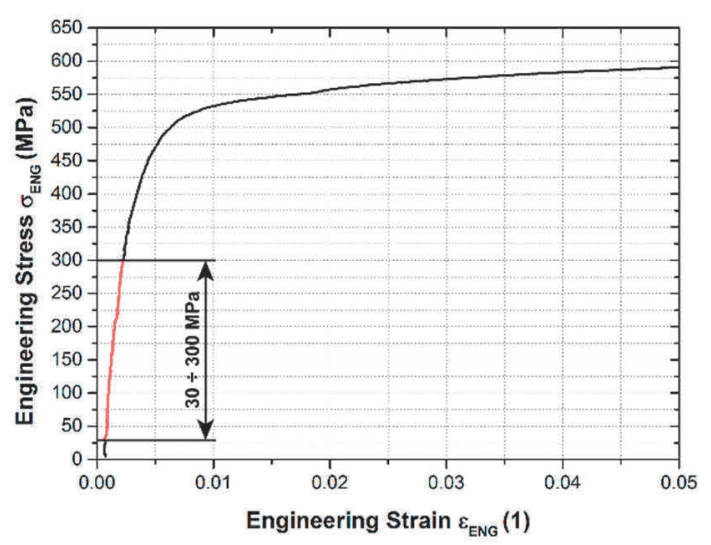

b) detail of selected data within elastic deformation

Figure 3 Engineering stress-strain curve and detail of selected data range from 30 up to $300 \mathrm{MPa}$ within elastic deformation - testing temperature $100^{\circ} \mathrm{C}$

Figure 4 shows these data within the interval from 30 up to $300 \mathrm{MPa}$ (again for $100{ }^{\circ} \mathrm{C}$ ). These "raw" data are shown in black colour. Red curve represents the applied linear fitting within this range, where the slope of this line is directly magnitude of the relevant Young's modulus $E(\mathrm{MPa})$. In this case (testing temperature of $100{ }^{\circ} \mathrm{C}$ ) is such value equals to $178505 \mathrm{MPa}$. The same procedure was then used for all tested temperatures.

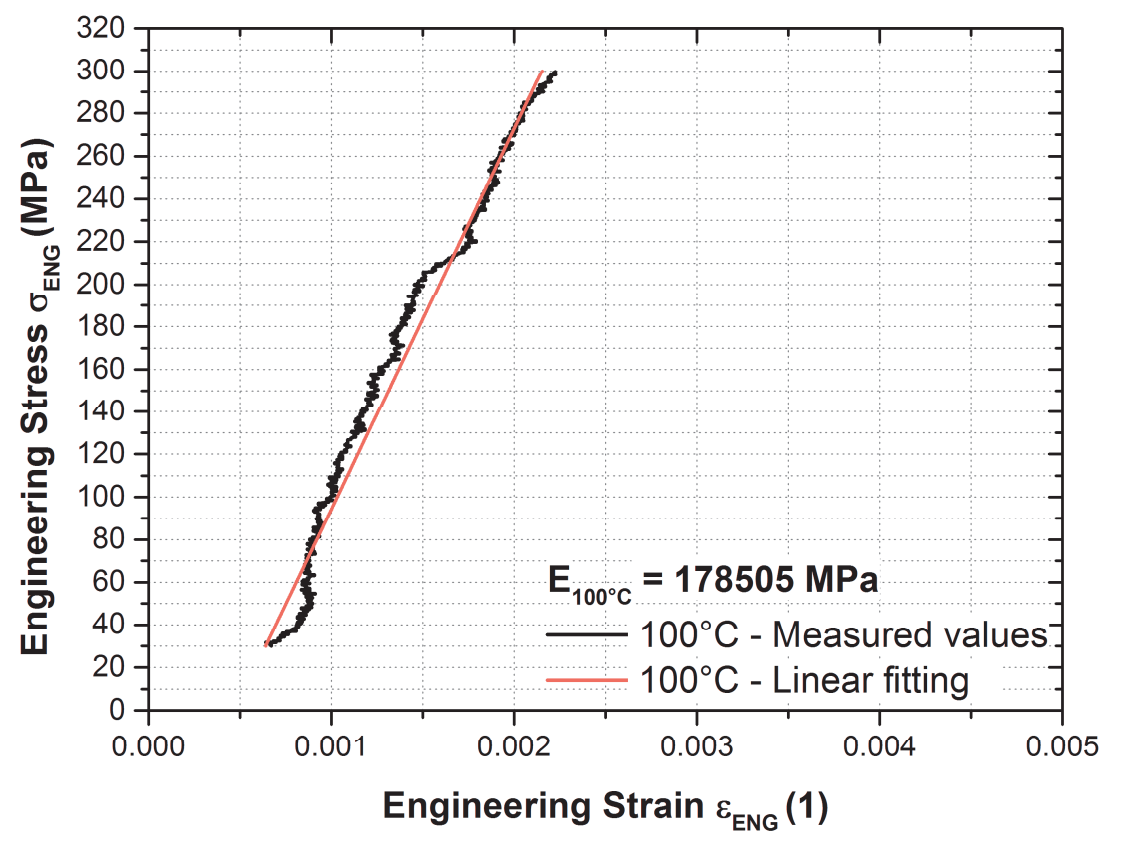

Figure 4 Linear fitting of measured data to obtain relevant Young's modulus (here for $100{ }^{\circ} \mathrm{C}$ ) 
In Table 2 are summarized all values of Young's modulus in dependence on testing temperature. There were always tested 5 samples for one testing temperature, so as results there are used arithmetic mean $\mathrm{x}$ and standard deviation s. Moreover, there are also mentioned percentage values both with respect to RT (taken as $100^{\circ} \mathrm{C}$ ) and percentage differences between measured temperatures - thus per $100^{\circ} \mathrm{C}$.

Table 2 Young's modulus vs. testing temperature for stainless steel DIN 1.4301

\begin{tabular}{|c|c|c|c|c|c|c|c|c|}
\hline \multicolumn{2}{|c|}{$\begin{array}{c}\text { Testing Temperature } \\
\qquad T\left({ }^{\circ} \mathrm{C}\right) \\
\end{array}$} & RT & $100^{\circ} \mathrm{C}$ & $200^{\circ} \mathrm{C}$ & $300^{\circ} \mathrm{C}$ & $400{ }^{\circ} \mathrm{C}$ & $500^{\circ} \mathrm{C}$ & $600^{\circ} \mathrm{C}$ \\
\hline \multirow{3}{*}{$\begin{array}{l}\text { Young's } \\
\text { Modulus } \\
E(\mathrm{MPa})\end{array}$} & $\begin{array}{c}\text { arithmetic } \\
\text { mean } \mathbf{x}\end{array}$ & 185035 & 178505 & 170892 & 163291 & 158997 & 146958 & 140709 \\
\hline & $\begin{array}{c}\text { standard } \\
\text { deviation } \mathbf{s}\end{array}$ & 457 & 895 & 954 & 942 & 1089 & 1124 & 1430 \\
\hline & $\begin{array}{c}\text { Percentage } \\
\text { regarding RT } \\
\left(\text { per } 100^{\circ} \mathrm{C}\right)\end{array}$ & $100 \%$ & $\begin{array}{l}96.47 \% \\
(-3.53 \%)\end{array}$ & $\begin{array}{l}92.86 \% \\
(-3.61 \%)\end{array}$ & $\begin{array}{l}88.73 \% \\
(-4.13 \%)\end{array}$ & $\begin{array}{l}86.40 \% \\
(-2.33 \%)\end{array}$ & $\begin{array}{r}79.85 \% \\
(-6.55 \%) \\
\end{array}$ & $\begin{array}{r}76.46 \% \\
(-3.39 \%) \\
\end{array}$ \\
\hline
\end{tabular}

Graphically are these results shown as column graph in Figure 5. There are illustrated average values and also standard deviations. Already from this graph (and Table 2 as well) are evident two basic dependences. First is about decrease of Young's modulus with increasing temperature as there was expected. Second variable means increasing standard deviation with increasing temperature. It seems that higher temperature has a negative effect on the accuracy of used optical system. At first, this effect looks to be not so important (increase by $973 \mathrm{MPa}$ in light of standard deviation), but on the other hand, every determination of Young's modulus is very sensitive on every device error and measurements (at least for $600{ }^{\circ} \mathrm{C}$ ) should be repeated.

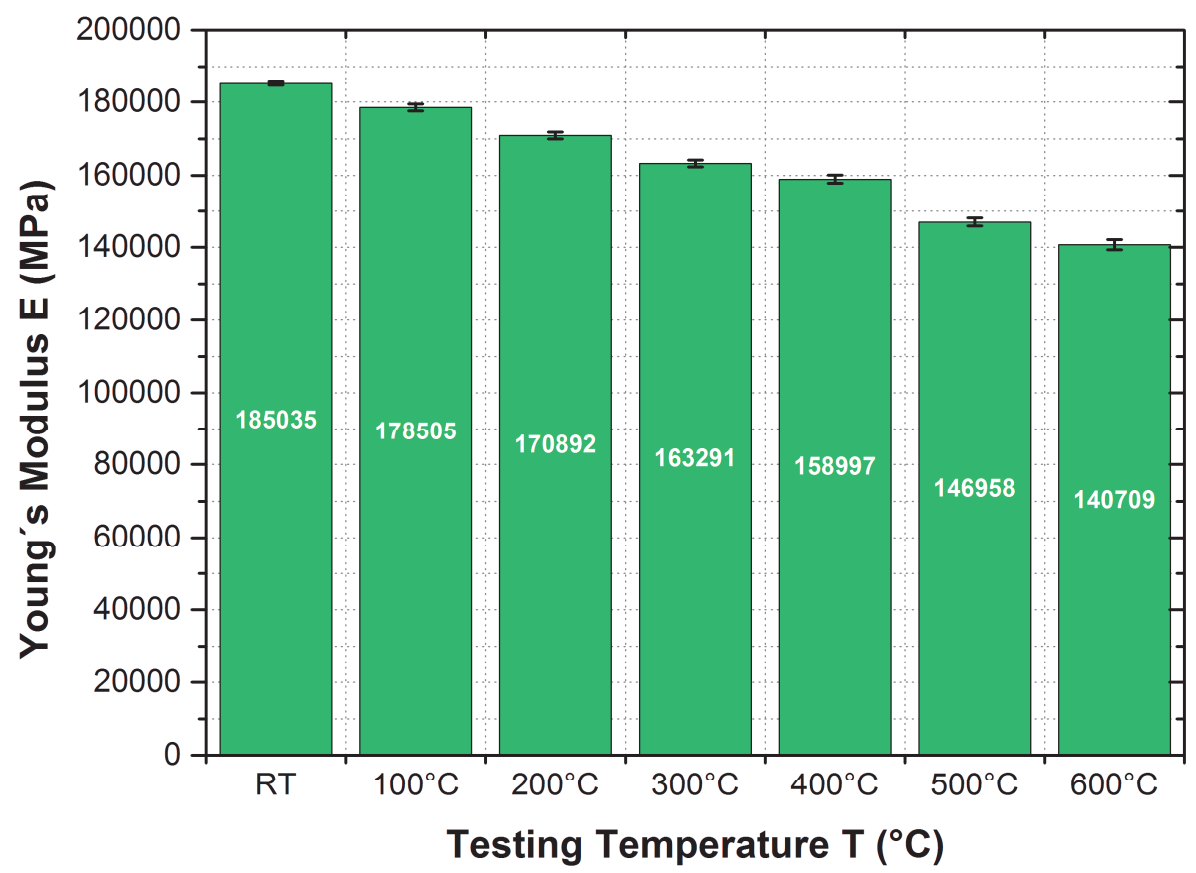

Figure 5 Young's modulus vs testing temperature

\section{CONCLUSION}

Nowadays, it is quite common to apply non-contact extensometers at material testing. Nevertheless, there are problems with temperature influence on the accuracy of such optical systems. And just utilization of the 
contact-less optical system to scan specimen's extension upon loading force at elevated temperatures was also used in the experimental part of this paper. As a testing material, there was selected the stainless steel DIN 1.4301. Although acc. to Davies [7] can be stated, that stainless steels are not extensively used in the nowadays automobile industry, they have already found their place in many commercial vehicles (e.g. buses). Surely, their excellent corrosion resistance is taken as major advantage of stainless steel. Moreover, they reveal excellent formability (high magnitudes of uniform ductility and total ductility - almost without necking zone). On the other hand, they are quite expensive that is their major disadvantage. All of these properties were taken into account during selection testing material for this paper. Nevertheless, there is strong presumption about testing more material groups by experimental methods described in this paper. The major aim of this paper was to determine influence of testing temperature on Young's modulus for austenitic stainless steel DIN 1. Two basic approaches were used to determine stress-strain curves, where their slopes in the elastic region represent the required magnitudes of Young's modulus. First ("conventional") method was used only at RT and used high accuracy extensometer Epsilon. All other testing temperatures (from $100{ }^{\circ} \mathrm{C}$ up to $600{ }^{\circ} \mathrm{C}$ ) were measured by the non-contact optical system Mercury. Mono-camera was used in this case. Subsequently, there was used the least square method to compute Young's modulus within the stress interval from 30 up to $300 \mathrm{MPa}$. Results confirmed tendency of Young's modulus to decrease with increasing temperature. It was lower by $76.46 \%$ in comparison between RT and $600{ }^{\circ} \mathrm{C}$. Steps between temperature intervals were mostly by $3.5 \%$ - expect $500{ }^{\circ} \mathrm{C}$, where it was by $6.5 \%$. These results also confirmed that there can be used photogrammetry to determine extension. On the other hand, it seems that sometimes there are some limits for such utilization, because standard deviation is much higher for $600{ }^{\circ} \mathrm{C}$ than RT or $100{ }^{\circ} \mathrm{C}$. However, there should be used high temperature axial extensometers to prove such conclusion. Generally, there is effort to create 3D charts of mechanical properties dependences (with testing temperature as X-axis and strain rate as $\mathrm{Y}$-axis) to be used in numerical simulations.

\section{ACKNOWLEDGEMENTS}

This publication was written at the Technical University of Liberec as part of the project "SGS 21280" with the support of the Specific University Research Grant, as provided by the Ministry of Education, Youth and Sports of the Czech Republic in the year 2019.

\section{REFERENCES}

[1] HOSFORD, W. F. and CADDEL, M. R. Metal Forming - Mechanics and Metallurgy. 3rd ed. Cambridge: Cambridge University Press, 2007. p. 312.

[2] HERTZBERG, R. W. Deformation and Fracture Mechanics of Engineering Materials. 4th ed. New York: John Wiley \& Sons, 1996. p. 786.

[3] ASHBY, M. F. Materials Selection in Mechanical Design. 3rd ed. Oxford: Butterworth-Heinemann, 2005. p. 603.

[4] KUHN, H., and MEDLIN, D. ASM HANDBOOK Volume 8 - Mechanical Testing and Evaluation. 10th ed. Materials Park: ASM International, 2000. p. 998.

[5] PÖHLANDT, K. Materials Testing for the Metal Forming Industry. Berlin: Springer-Verlag, 1989. p. 226.

[6] TRIPATHY, H., HAJRA, R. N., SUDHA, C., RAJU, S. and SAIBABA, S. Measurement of high temperature elastic moduli of an $18 \mathrm{Cr}-9 \mathrm{Ni}-2.95 \mathrm{Cu}-0.58 \mathrm{Nb}-0.1 \mathrm{C}$ (Wt \%) austenitic stainless steel. In: AIP Conference Proceedings [online]. 2018. Available from: https://www.scopus.com/inward/record. uri?eid=2-s2.085046083468\&doi=10.1063\%2f1.5031717\&partnerID=40\&md5=de3d0c9e96d25adfdab814cff2b42d5a

[7] DAVIES, G. Materials for Automobile Bodies. Oxford: Butterworth-Heinemann, 2003. p. 277. 